Grand Valley State University

ScholarWorks@GVSU

Spring 2004

\title{
Caroline Bartlett Crane and Municipalsanitation: Applied Sociology in the Progressive Era
}

Linda Rynbrandt

Grand Valley State University

Follow this and additional works at: https://scholarworks.gvsu.edu/soc_articles

Part of the Sociology Commons

\section{ScholarWorks Citation}

Rynbrandt, Linda, "Caroline Bartlett Crane and Municipalsanitation: Applied Sociology in the Progressive Era" (2004). Peer Reviewed Articles. 8.

https://scholarworks.gvsu.edu/soc_articles/8

This Article is brought to you for free and open access by the Sociology Department at ScholarWorks@GVSU. It has been accepted for inclusion in Peer Reviewed Articles by an authorized administrator of ScholarWorks@GVSU. For more information, please contact scholarworks@gvsu.edu. 


\title{
CAROLINE BARTLETT CRANE AND MUNICIPALSANITATION: APPLIED SOCIOLOGY IN THE PROGRESSIVE ERA
}

\author{
Linda Rynbrandt \\ Grand Valley State University
}

ABSTRACT

Applied Sociology occupies contested territory between academic sociology and social activism. An examination of applied sociology at the turn of the $20^{\text {th }}$ century, as practiced by Caroline Bartlett Crane, Unitarian minister and Progressive Era social reformer, provides an excellent case study of these disciplinary debates. This article examines Crane's efforts to utilize the new discipline of sociology to improve society through municipal sanitation. Sociology and community social reform were often closely linked in the Progressive Era. Early reformers and applied sociologists involved in sociology at the turn of the $20^{\text {th }}$ century would likely be puzzled by the academic focus of the field today and dismayed by the privileged position of scholarship over social reform in contemporary sociology. One can only question how sociology's mission and message might differ today if the legacy of early, community-based sociology was more widely known within the discipline.

If the history of sociology is a contentious arena, the history of sociology outside of the academy is even more so. Questions of identity, definition, mission, and methods surrounded sociology from the beginning; and they persist to the present moment. What is sociology? What are the goals of sociology? Who qualifies as a sociologist? These questions echo through the years. Early sociologists debated issues of social reform vs. objective research, disciplinary boundaries and research methods in a battle, broadly drawn, between academic sociology on the one hand and social activism on the other. Applied sociology occupies contested territory between these two extremes.

An examination of applied sociology at the turn of the twentieth century, as practiced by Caroline Bartlett Crane, Unitarian minister and Progressive Era social reformer, provides an excellent case study of these disciplinary debates (Rynbrandt, 1999). This article examines Crane's efforts to utilize the new discipline of sociology to improve society through municipal sanitation. The

Journal of Applied Sociology/Sociological Practice, Vol. 21 No. 1/ Vol. 6 No. 1, S pring 2004: 84-94. (C) Society for Applied Sociology and the Sociological Practice Association 


\section{Rynbrandt: Caroline Bartlett Crane}

liminal experiences (past and present) of individuals outside of academic sociology illustrate boundary and identity issues that still perplex sociology today. Sociology and community social reform were often closely linked in the Progressive Era. Early reformers and applied sociologists involved in sociology at the turn of the twentieth century would likely be puzzled by the academic focus of the field today and dismayed by the privileged position of scholarship over social reform in contemporary sociology. One can only question how sociology's mission and message might differ today if the legacy of early community based sociology was more widely known within the discipline.

\section{CAROLINE BARTLETT CRANE (1858-1935)}

Caroline Bartlett was born in Hudson, Wisconsin in 1858. Her father was a Mississippi River steamboat captain, among other occupations, during her childhood and youth. Her mother devoted a great deal of time and energy to the care of Caroline's frail younger brother. As a consequence, Caroline breached tradition and became closely attached to her father, rather than focus on her mother's more domestic pursuits. Caroline's father encouraged her educational goals, and in 1879 Caroline graduated as class valedictorian from Carthage (Illinois), College. As one of the first generation of women college graduates (1860-1880) in the United States, Caroline faced unusual challenges and opportunities. She was much better educated than women in previous generations, but few professional positions had been created to enable these able and eager women to fulfill their potential (Solomon, 1985). Women, such as Caroline Bartlett Crane, struggled to find their place in the world as an educated person.

To compound the problem for Caroline, early on she determined to be not only a well educated women in a world only slowly accepting that status, but she also decided that her life's goal was to enter the liberal ministry. Although her parents had encouraged her goal to pursue a college degree, they did not approve of her desire to enter the ministry in an era in which this was perceived as a highly improper profession for women. Therefore, she followed a typical path for educated women in that period, first becoming a teacher and later a journalist to fill the time until she could enter the profession of her choice. Although she was not allowed to attend seminary, she eventually received private instruction and was ordained into the Unitarian ministry in Kalamazoo, Michigan in 1889. She was one of the first ordained women to occupy a pulpit in Michigan, and immediately began to use her church as a vehicle for social reform. In order to provide the best possible social 
improvements in her own community, she traveled to England 1891 to observe the new settlement and charity work of the Toynbee House settlement and the Salvation Army in London. In addition, she attended graduate classes in sociology at the University of Chicago in the summer of 1896 to further her efforts toward social justice and reform.

Soon she refocused her small, failing congregation into a highly successful institutional church renamed People's Church, which focused as much on secular social improvement in this world as it did on the salvation of souls in the world to come. Not content to facilitate social reform in her local community, she moved rapidly to promote social reform through local sociology clubs based on social research and social action across the nation.

She differed from many of her contemporaries in Progressive Era reform for whom marriage and a career seemed incompatible. In 1896, Caroline married Dr. Augustus Crane, a local physician ten years her junior. Noted woman suffrage reformer Susan B. Anthony and Crane's local congregation expressed concern regarding the impact of marriage on her ministry and work in social reform. Their apprehensions may have seemed justified when Crane resigned from her formal church duties in 1898, and on the advice of her husband took a two year hiatus from public life.

When she returned to public life she did not reenter the formal Unitarian ministry, but began a career in "public housekeeping" -- which may have seemed more in keeping with her status as a married women. Her new career in municipal sanitation eventually entailed scientific social sanitary surveys of over 62 cities in fourteen states and led to national recognition as a social reformer. Throughout her career in social housekeeping, Crane utilized her sociological training and imagination in her efforts for social reform. Clearly, Crane was an exceptional woman living in an exciting time. Industrialization, immigration, and urbanization converged to create huge social dislocations, and new sciences, such as sociology, emerged to help understand and ameliorate vexing social problems.

As we look back into the history of sociology, names such as Karl Marx, Emile Durkheim, and Max Weber come to mind. But where are Jane Addams, Caroline Bartlett Crane, and the many other women and men on the margins of sociology at this important period of the history of the discipline? When Crane began her career, she frequently referred to her work as "sociology," but by the end of her career, she had redefined her activities as social work. I would argue, however, that Crane was a sociologist, and that her career in sociology should be reconsidered. In a more inclusive definition of a 


\section{Rynbrandt: Caroline Bartlett Crane}

sociologist, Dirk Kasler suggested the following criteria for membership in the profession of sociology (quoted in Deegan, 1988: 9):

- occupy a chair of sociology and/or teach sociology

- membership in the .... American Sociological Society

- coauthorship of sociological articles or textbooks

- self-definition as a sociologist

- definition by others as a sociologist

On the basis of at least three or four of these criteria, I would consider Crane to be a sociologist. Crane herself noted in 1896, that "the science of sociology is in an extremely inchoate and tentative state, and.... head professors do not yet agree as to some of the first principles thereof" (1896:.382). In this ambiguous environment, Crane worked with sociologists in academe, promoted sociology to audiences large and small, called her work applied sociology, wrote about sociology and was listed as a sociologist in numerous obituary accounts following her death in 1935. The balance of this article highlights some of Crane's connections with sociology in the early days of the discipline. Her work might well be utilized as a "road not taken" in the increasingly academic, professional and empirical sociology of the twentieth century, and offer insights into potentials for sociology in the twenty-first century.

\section{SOCIOLOGY BEGINS AT HOME}

Early sociology was a curious mix of the academic and the applied. Homegrown experts jockeyed for position in the community, the church, and in the ivory towers of academe. Social problems were evident, social solutions were less certain. Academics, experts, and lay-workers labored together to promote social welfare and justice in an era where needs were great and boundaries between amateurs and professionals, as well as between the academy and community life were less firmly entrenched. In 1896, Crane started the Unity Club at People's Church in order to study sociology and social conditions at the local level. Her group investigated the various social services and public health efforts offered by the city of Kalamazoo: the food and water supply, waste disposal, housing, air pollution, street sanitation, and the condition of local institutions such as schools, jails and the poor house. In the 1897 Annual Report of People's Church, Crane noted: 
During 1896-1897, the Unity Club, having followed sociology for some years, did a fine work in "A Study of the Social Conditions of Kalamazoo" -- reporting investigations made, illustrated with tables, maps, and diagrams. The work was submitted to the department of sociology of the University of Chicago, and received high commendations, some of the material being used by the University of Chicago in illustration of methods of the scientific study of local social conditions (Annual Report, 1897: 4)

Crane contended, however, that "the object is not merely to obtain information, but information of a kind that will lead to more rational methods in endeavoring to improve the sociological condition of our city" (Church Calendar: 25). In keeping with Crane's pragmatic philosophy, although accurate information was crucial for social reform, information was never to be an end in itself.

Crane's views and efforts were reflected in the May 1897 issue of the American Journal of Sociology, as University of Chicago doctoral student I.W. Howerth (1897: 852) wrote:

The present widespread discontent in regard to social conditions ... and the growing belief that better conditions may be realized if we set about it intelligently, make the study of the actual facts of society one of the chief demands of the times.... Theoretical study should not be discouraged, of course, but the formation in a few cities of study clubs to pursue local social investigations marks the beginning of a movement which also deserves the encouragement of everyone interested in social reform.

In addition to her concern for Kalamazoo, Crane, encouraged the formation of local sociology clubs in other cities. For example, in a speech before a group in Milwaukee she noted:

It [sociology] teaches us to go personally among all classes of men and women, to feel with them and for them; to observe their customs and conditions and to draw inductions from what we find. Today the greatest geologist sends his student not to books, but to rocks, and the astronomer his student not to charts, but to the telescope. Thus it must be with him who would study sociology in the scientific way. It is vastly more useful to study our own social environments than conditions which are foreign to us. You are undertaking here, as we last year undertook to do 
in Kalamazoo, to study things at first hand (Sociology as a Study, ca. 1897).

To further this cause, Crane also promoted scientific social reform to large audiences of clubwomen and others interested in social justice and reform. For example, she spoke at the 1896 Biennial Convention of the General Federation of Women's Clubs, the 1891 National American Woman Suffrage Association convention in Washington, D.C. and she often addressed groups such as 1903 Annual Convention of the Michigan State Conference of Charities and Corrections. Clearly, in the Progressive Era, the promotion and practice of sociology was not limited to primarily male professors in the academy, as contemporary historical accounts of the discipline would suggest.

\section{CLEAN STREETS, MEAT INSPECTION, AND THE POOR HOUSE}

Crane and other Progressive Era reformers were involved in a wide variety of social reform efforts intended to foster a range of reforms, from public health to social justice. Throughout her long career in reform, Crane endeavored to promote municipal sanitation, pure food laws, low cost housing, woman suffrage, temperance, poor house reform, welfare reform, pollution control, environmental issues and world peace. This is an ambitious list. This may seem to cover a wide variety of concerns, but in reality Crane's goal was simply to promote an environment in which everyone would have the opportunity to achieve their fullest potential. She believed that this could be done by careful research into the causes of social problems combined with the education of the public officials, and the public in general, regarding the best solutions to these problems. An environmental approach to the solution of social problems was widely shared by Progressive Era reformers and academic sociologists in that period.

Women reformers in the Progressive Era armed themselves with the methods of the new social sciences in their attempt to improve the world. They also transformed traditional rhetoric regarding women's social roles to justify and facilitate their work in social reform. They embraced the notion that women's place was in the home, but redefined the nature of home to encompass any aspect of the physical and social environment that might impact their ability to protect their 
Journal of Applied Sociology/Sociological Practice, 21, 1/6, 1,

own home and family. How was a woman to keep a clean house and raise a healthy family if the streets were dirty and the food was impure? And, if women were able to clean up the environment and improve the food supply, how were those improvements to be maintained if women were not allowed the vote to keep corrupt politicians from going back to business as usual? Consequently, women marched bravely into the public world of politics, in the name of their private domestic duties. The city was their home and it was in the interest of everyone to strive for a healthy environment. For example, in a speech in Baltimore in 1911, Crane noted:

Of what avail is it if the city is called rich and great, if the elect few dwell in palaces and wear costly fabrics and dine sumptuously every day, and the homes of the common people are sordid and unsafe and unbeautiful, and made so by the city's short-sightedness or greed? Sometimes scourges which develop in a neglected quarter have a way of sweeping past ward lines and smiting the homes of the rich. Housekeeping, public or private, is not an end in itself; it is that we may foster homes (1911a: 224).

In addition to their responsibility to their greater home, the city, women were also to be concerned with all children, not merely their own. Crane insisted that "we want to make the streets of our city a safe place for the children. Whatever you are doing for other children you are doing also for you own (1911a: .225). She concludes, "for the most selfish reasons - and the most unselfish reasons, you want to make this city of yours a good place, ... for all your young. And it is a good city, a good world, in which the children are safe" (1911a: .225). In addition to children, Crane also advocated for the elderly, poor and other infirm individuals in community almshouses across the nation. She fought for health care and a safe, clean environment for these "forgotten people" (Crane, 1904).

Throughout her career in reform, Crane argued that women were not merely interested in short-term solutions to problems in society. Although she advocated social reform to enhance the lives of individuals, Crane located the origins of social problems in social structures, not individuals (Crane, 1896). Therefore, social change must be systemic and ongoing. Still, she brought large social issues, such as injustice and poverty right back to the individual woman and 


\section{Weinstein: Sociological Know-How}

her kitchen. She advocated consumer boycotts, not unlike contemporary efforts to fight global sweatshops (Friedman, 2000: 178), and advised clubwomen to purchase goods only from business organizations that were sanitary and treated their employees well. For example, she challenged women consumers when she asked, "Do we ever thoughtlessly purchase garments at prices that are starvation or heartbreak or ruin to some poor woman who makes them? Do we always remember that the social problem is in our kitchen?" (Crane, 1896: .383)

\section{CONCLUSION}

Crane put her interest in public health and social justice into action through her efforts with the Unity Club at People's Church in Kalamazoo, early in the twentieth century. Along with other women in the community she endeavored to clean the streets, inspect food suppliers and set standards for meat inspection in order to facilitate health and safety. As homemakers, the women believed they were serving their families and community through their expertise as housekeepers on a larger scale. In conjunction with local women's clubs, Crane also fought to promote social justice through poor house and welfare reform, women's rights and pollution control in poor neighborhoods.

Within a short period of time, Crane was invited to visit other cities and evaluate their municipal sanitation systems. She utilized local clubwomen to help her collect data and investigate city facilities (Rynbrandt, 1997). Although she believed that scientific, empirical research must precede social reform, and she published reports of all of her survey research to facilitate further social research, Crane insisted that the purpose of research was never merely to acquire knowledge as an end in itself. In a published report of her sanitary survey of cities in the state of Minnesota, she noted:

The purpose of this campaign, briefly stated, was, to help communities to understand and to improve the material conditions under which the people live; to bring into the public mind the consciousness of the city as the larger home, and to show that sordid and unwholesome conditions of life for even the poorest people should be regarded as something affecting the larger family. (Crane, 1911b: 7) 


\section{Journal of Applied Sociology/Sociological Practice, 21, 1/6, 1,}

Crane's contemporary Jane Addams was also a civic housekeeping advocate who worked closely with academic sociologists at the University of Chicago (Deegan, 1988). She shared Crane's goal of democratic grass-roots reform, rather than using social research as a tool to study a client population and promote a top-down approach to reform. Although Addams and her Hull-House staff gathered and published social data, she rejected academic sociology's request to use her settlement house as a laboratory experiment (Elshtain, 2002: 85). Hull House residents were committed to social reform, but they were to be good neighbors, not case managers in this quest.

Crane also intended her applied sociology to provide a model for reform. She insisted that the ultimate goal was not to come into a city, suggest a professional map for civic and social improvement and consider the task finished. Her purpose was to empower individuals (especially women) within each city to identify problem areas, promote improvements and monitor those positive changes -- long after she herself had left the scene -- in a democratic, communitybased approach to social reform.

\section{EPILOGUE}

This brings us full circle back to questions raised at the beginning of this article. Critiques of sociology come from outside of the discipline and, most especially, from within. Is sociology really a science, or is it a social reform movement? Should sociology be content to describe the social world, or should sociology prescribe alternatives? Even if we could agree on goals, which research method/s best achieve those goals? Does sociology as a discipline struggle for identity and status because it is too oriented to quantification or because it is too focused on moral concerns outside of the arena of an empirical, scientific discipline? These are not idle questions, but they strike at the heart of the discipline and the identity of sociologists.

Crane's life and work suggest alternative possibilities for the discipline as opportunities opened for some and closed for others in early sociology. Blocked aspirations often led to creative, innovative solutions as new occupations and disciplines were formed in response to resistance in academic sociology. This lost (or nearly forgotten) legacy can only enrich our sociological heritage and clarify our 


\section{Weinstein: Sociological Know-How}

present focus as a discipline at the beginning of the twenty-first century.

\section{REFERENCES}

Annual Report 1897. In the Caroline Bartlett Crane Collection, Western Michigan University Archives and Regional History Collections, Kalamazoo, Michigan.

Church Calendar 1896-1897. In the Caroline Bartlett Crane Collection, Western Michigan University Archives and the Regional History Collection, Kalamazoo, Michigan.

Crane, Caroline Bartlett. 1896. "The Word of the Spirit." The New Unity, pp. 382-384. In the Caroline Bartlett Crane Collection, Western Michigan University Archives and the Regional History Collection, Kalamazoo, Michigan.

Crane, Caroline Bartlett. 1904. "Women's Clubs as Related to Penal and Pauper Problems." Address to the Michigan Conference of Charities and Corrections $23^{\text {rd }}$ annual convention. In the Caroline Bartlett Crane Collection, Western Michigan University Archives and Regional History Collections, Kalamazoo, Michigan.

Crane, Caroline Bartlett 1911a. "Municipal Housekeeping." Baltimore. Reprinted from Proceedings of Baltimore City-Wide Congress, March 8-10, 1911: 205-225. In the Caroline Bartlett Crane Collection, Western Michigan University Archives and Regional History Collections, Kalamazoo, Michigan.

Crane, Caroline Bartlett 1911b. "Introduction." Report of a Campaign to Awaken Public Interest in Sanitary and Sociologic Problems in the State of Minnesota: 7-12. Saint Paul, MN: Voldszeitung.

Deegan, Mary Jo. 1988. Jane Addams and the Men of the Chicago School, 1892-1918. New Brunswick, NJ: Transaction Books. 
Journal of Applied Sociology/Sociological Practice, 21, 1/6, 1,

Elshtain, Jean Bethke. 2002. Jane Addams and the Dream of American Democracy. New York: Basic Books.

Friedman, Thomas. 2000. The Lexus and the Olive Tree: Understanding Globalization. New York: Anchor Books.

Howerth, I.W. 1897. "A Programme for Social Study." American Journal of Sociology 11, 6: 852-72.

Rynbrandt, Linda. 1997. 'The 'Ladies of the Club' and Caroline Bartlett Crane: Affiliation and Alienation in Progressive Social Reform" Gender and Society 11: 200-214.

Rynbrandt, Linda. 1999. Caroline Bartlett Crane and Progressive Reform: Social Housekeeping as Sociology. New York: Garland.

Sociology as a Study ca.1897. Unidentified newspaper clipping, Milwaukee. In the Caroline Bartlett Crane Collection, Western Michigan University Archives and Regional History Collections, Kalamazoo, Michigan.

Solomon, Barbara. 1985. The Company of Educated Women: $A$ History of Women and Higher Education in America. New Haven, CT: Yale University Press. 